\title{
Comparative Analysis of Hotel Classification and Quality Mark in Hospitality
}

\author{
Diana Foris \\ Transilvania University of Brasov, Brasov, Romania
}

\begin{abstract}
This article makes a comparative analysis of hotel classification and quality mark in hospitality, aiming, primarily, to eliminate the confusion among these concepts regarding the role, the objectives, the procedures, and the purpose of these regulations and instruments used in the hotel industry. In this sense, the concepts of hotel classification (classification systems of the European Union (EU) member states) and the quality mark in hospitality (within the EU countries) are analyzed. The research methodology involved activities of collecting, processing, and interpreting information on issues of classification and quality brand in the hotel industry, nationally and internationally, using a vast amount of documentary material (books, studies, journals, legal regulations, Internet databases, etc.), making objective and analytical observations, theoretical analysis, benchmarking, and content analysis. The research results provide information which eliminates the confusion between the two concepts, providing clarification on the role, objectives, and procedures of the hotel classification purposes, namely, quality label in hospitality. Research highlights the similarities and especially the differences between the hotel classification and the quality mark in hospitality. The conclusions of this paper contribute to clarifying concepts: hotel classification and quality mark in hospitality, including important and useful information for the specialists in tourism and business operators in the hotel industry. In this regard, hotel classification is a coded form of synthesis of the comfort level and range of services, and the quality label is a model of good practices for implementation and certification of the hotel services quality. The classification system may be compulsory or voluntary (varies from country to country), while the quality mark is always voluntary. Classification of hotels is based on the star system (1-5 stars), and the quality brand is based on awarding the quality mark symbol.
\end{abstract}

Keywords: hotel, hospitality, hotel classification, quality mark in hospitality

\section{Introduction}

Taking into account that tourism consumers are more informed and more pretentious when it comes to the quality and quantity of the touristic services, we find that the classification of tourist accommodations, as well as the quality certification of hotel services, has become essential requirements on the tourism service market.

The classification of tourist structures represents an encoded form of synthesis of the comfort level and range of services and is based on reputation, moral climate, and a set of service standards.

The quality mark is a model of best practices for the implementation and certification of quality hotel services as a voluntary option in the field of economic operators in order to improve the quality of services

Diana Foris, Ph.D., lecturer, Faculty of Food and Tourism, Transilvania University of Brasov. Email: diobb@yahoo.com; diana.foris@unitbv.ro. 
provided by the hotel units in order to increase customer satisfaction and ensure them that they will benefit in any hotel units assessed and certified by a high level of service quality, regardless of the category of classification unit.

\section{Analysis of Classification Systems of Tourist Accommodation in the European Union (EU) Countries}

Classification of tourist accommodation is a coded form which would synthesize the comfort level and range of services related to the specific category (Foris, 2011).

The objectives taken into consideration through adopting an official classification system can be:

(1) Customers' information;

(2) The possibility to distinguish tourism accommodation structures, by implementing differentiated policies;

(3) The possibility of a higher tax burden from the state to the products (luxury hotels);

(4) A possible tariff regulation;

(5) Facilitate communication, contract closing and monitoring, in the relationship between hotels and travel agencies.

Each of the world's countries, due to cultural and national traditions, appeals to a specific classification system, which prevents the application of a single classification system in the world (The European Consumer Centres' Network, 2009).

The criteria for classification of tourist accommodation, taken into consideration by OMT, are the following (The European Consumer Centres' Network, 2009, pp. 5-6):

(1) Comfort level:

(a) Superior (luxury, 4- and 5-star);

(b) Medium (3-star);

(c) Modest (1- and 2-star).

(2) Territorial location:

(a) Seasonal;

(b) Mountain;

(c) Climatic hydropathic areas;

(d) Urban;

(e) Rural;

(f) Outside the cities, close to circulated areas.

(3) Functionality motivation/length of stay:

(a) Transit;

(b) Special motivation (stay).

(4) System operation:

(a) Permanent;

(b) Seasonal.

(5) Exploitation method:

(a) Individual services;

(b) Associations (voluntary professional chains); 
(c) Companies or groups (hotel chains).

(6) Ownership:

(a) Personal ownership;

(b) Private;

(c) Governmental;

(d) Joint;

(e) Public ownership;

(f) Public property of international concern;

(g) Time-sharing.

(7) Capacity:

(a) Reduced (small hotels, up to 150 beds);

(b) Medium (medium hotels, 150-400 beds);

(c) Large (large hotels, over 400 beds).

(8) Target:

(a) Business;

(b) Interest;

(c) Holiday.

(9) Service standards and offered facilities:

(a) Complete;

(b) Economic;

(c) Self-catering.

One of the criteria for the basic classification is the level of comfort, and it is composed of the following parameters:

(1) Surface (sqm) of the tourist location, of public spaces, rooms (according to the number of beds), the number of the touristic spaces, utilities;

(2) Conditions of offering suitable furniture, inventory, and sanitation utilities;

(3) The presence and type of catering services;

(4) Construction, access, and landscape;

(5) Providing technical services, including telephony, Internet, TV reception, the facilities with TV, fridge, minibar, safe, etc.;

(6) Possibility and offering of additional services.

To understand the essence of the classification of tourist system in terms of comfort level, the most important aspect is the regulatory activity of international practices, which are two different approaches in rule-making classification:

(1) Rule-making is ensured by the authorities/institutions of the state (the case of the national classification system);

(2) Rule-making is provided by the unions or professional organizations (e.g., Hotelstars).

In this respect, various authorities/public institutions, professional organizations, and companies assumed responsibility to elaborate rules and regulations for classification of the touristic structures.

Classification of tourist structures, as a coded form of synthesis of the comfort level and range of services, is based on awareness, moral climate, and a set of standard services. 
According to the adopted classification system, countries can be divided into the following categories:

(1) States which do not have an official classification system (e.g., the Nordic countries) - justification based on the principles of freedom of the market and the objection of any form of intervention and control;

(2) States which do not adopt an official classification system, but which have a recognized informal classification system (e.g., the Great Britain whose classification system is introduced by two automobile associations: the Automobile Association and the Royal Club of Automobiles; Denmark whose system of "best practices" is introduced by "Politiken"; Switzerland, Germany, etc., the professional associations of hoteliers);

(3) States which have an official system of classification, more or less detailed (e.g., Romania, Italy, Greece, Holland, Luxemburg, Bulgaria, France - considered as being one of the most complex classification systems).

Considering that the hotel is the most important type of touristic structure, we will present types of hotel classification systems and the authorities/organizations responsible for their implementation in the member states of the EU (see Table 1).

Table 1

Types of Hotel Classification Systems of Hotels and Authorized Authorities/Organizations of Member States of the $E U$

\begin{tabular}{|c|c|c|c|}
\hline No. & Country & Type of hotel classification system & Responsible authorities/organizations' comment \\
\hline 1 & Austria & $\begin{array}{|llr|}\begin{array}{l}\text { Voluntary } \\
\text { (optional) }\end{array} & \text { national system } \\
\end{array}$ & $\begin{array}{l}\text { Hotelstars system through Austrian Professional Hotel } \\
\text { Association }\end{array}$ \\
\hline 2 & Belgium & Mandatory official regional system & $\begin{array}{l}\text { The Flemish part: Tourisme Vlaanderen } \\
\text { The Walloon part: The General Commissary of Tourism } \\
\text { Brussels: French Community Commission, Commissary for } \\
\text { Tourism }\end{array}$ \\
\hline 3 & Bulgaria & Mandatory official national system & State Agency for Tourism under the Ministry of Economy \\
\hline 4 & Cyprus & Mandatory official national system & National Tourism Organization of Cyprus \\
\hline 5 & Czech Republic & $\begin{array}{|ll|}\begin{array}{l}\text { Voluntary } \\
\text { (optional) }\end{array} & \text { national system } \\
\end{array}$ & $\begin{array}{l}\text { Hotelstars system through National Association of Hotels and } \\
\text { Restaurants of Czech Republic }\end{array}$ \\
\hline 6 & Croatia & Mandatory official national system & Ministry of Tourism \\
\hline 7 & Denmark & $\begin{array}{l}\text { Mandatory national system of } \\
\text { "good practices" for Horesta } \\
\text { members }\end{array}$ & $\begin{array}{l}\text { National Association of Hotels, Restaurants, and Tourism } \\
\text { Activities (hotels should have a minimum capacity of } 40 \\
\text { beds) }\end{array}$ \\
\hline 8 & Estonia & $\begin{array}{|ll|}\begin{array}{l}\text { Mandatory national system } \\
\text { Voluntary } \\
\text { (optional) }\end{array} & \text { national } \quad \text { system } \\
\end{array}$ & $\begin{array}{l}\text { Local public authorities (urban and rural) } \\
\text { Hotelstars system from } 2011\end{array}$ \\
\hline 9 & Finland & $\begin{array}{l}\text { Does not have a classification } \\
\text { system }\end{array}$ & $\begin{array}{l}\text { Websites and feedback from tourists (there is no objective } \\
\text { criterion) }\end{array}$ \\
\hline 10 & France & $\begin{array}{l}\text { Voluntary national } \\
\text { (optional) from June 2009 } \\
\text { Until June 2009, there was a } \\
\text { mandatory national system }\end{array}$ & $\begin{array}{l}\text { Legal regulation of the classification system can be found in } \\
\text { the Code of Tourism } \\
\text { Classification is performed by Atout France-France Tourism } \\
\text { Development Agency }\end{array}$ \\
\hline 11 & Germany & $\begin{array}{l}\text { Voluntary national } \\
\text { (optional) }\end{array}$ & $\begin{array}{l}\text { Hotelstars system through Deutsche Hotel-und } \\
\text { Gasttattenverband-Federal Confederation of German Hotels } \\
\text { and Restaurants }\end{array}$ \\
\hline 12 & Greece & Mandatory official national system & National Organization of Tourism \\
\hline 13 & Ireland & Mandatory official national system & Failte Ireland—-state organism \\
\hline 14 & Italy & Mandatory official regional system & Regional authorities of autonomous provinces \\
\hline 15 & Latvia & $\begin{array}{|llr|}\begin{array}{l}\text { Voluntary } \\
\text { (optional) }\end{array} & \text { national } & \text { system } \\
\end{array}$ & LLC-Hotel and Restaurant Centre \\
\hline
\end{tabular}


(Table 1 continued)

\begin{tabular}{|c|c|c|c|}
\hline No. & Country & Type of hotel classification system & Responsible authorities/organizations' comment \\
\hline 16 & Lithuania & Mandatory official national system & $\begin{array}{l}\text { Classification Commission of Accommodation Services } \\
\text { within the State Department of Tourism under the Ministry of } \\
\text { Economy }\end{array}$ \\
\hline 17 & Luxembourg & \begin{tabular}{|ll}
$\begin{array}{l}\text { Voluntary } \\
\text { (optional) }\end{array}$ & national \\
\end{tabular} & $\begin{array}{l}\text { Benelux Hotel Classification System through the Ministry of } \\
\text { Tourism }\end{array}$ \\
\hline 18 & Malta & Mandatory official national system & The Authority for Tourism of Malta \\
\hline 19 & Great Britain & \begin{tabular}{|ll}
$\begin{array}{l}\text { Voluntary } \\
\text { (optional) }\end{array}$ & national system \\
\end{tabular} & $\begin{array}{l}\text { Board of Tourism in England-Quality in Tourism, AA Hotel } \\
\text { Services }\end{array}$ \\
\hline 20 & Holland & $\begin{array}{|ll|}\begin{array}{l}\text { Voluntary } \\
\text { (optional) }\end{array} & \text { national } \\
\end{array}$ & $\begin{array}{l}\text { Hotelstars system through the Dutch hotel and catering } \\
\text { associated companies }\end{array}$ \\
\hline 21 & Poland & Mandatory official national system & $\begin{array}{l}\text { Ministry of Sport and Tourism, respectively, Voivodeship } \\
\text { Marshal in Warsaw }\end{array}$ \\
\hline 22 & Portugal & Mandatory official national system & $\begin{array}{l}\text { Tourism of Portugal (National Authority for Tourism of } \\
\text { Portugal) under the authority of Ministry of Economy, } \\
\text { Innovation, and Development }\end{array}$ \\
\hline 23 & Romania & Mandatory official national system & $\begin{array}{l}\text { Ministry of Economy through the National Authority for } \\
\text { Tourism }\end{array}$ \\
\hline 24 & Slovakia & Mandatory official national system & Ministry of Economy \\
\hline 25 & Slovenia & Mandatory official national system & Board of Tourism in Slovenia \\
\hline 26 & Spain & Mandatory official regional system & In each region (community) autonomous \\
\hline 27 & Sweden & \begin{tabular}{|ll}
$\begin{array}{l}\text { Voluntary } \\
\text { (optional) }\end{array}$ & national system \\
\end{tabular} & $\begin{array}{l}\text { Starting with } 2010-\text { Hotelstars system through the } \\
\text { classification committee of Swedish Hotel and Restaurant } \\
\text { Association (SHR) }\end{array}$ \\
\hline 28 & Hungary & \begin{tabular}{|l}
$\begin{array}{l}\text { Mandatory national system } \\
\text { Voluntary } \\
\text { (optional) }\end{array}$ \\
\end{tabular} & $\begin{array}{l}\text { Mandatory national system through the Office of Licensing of } \\
\text { Activities and Professions in Hungary } \\
\text { Hotelstars system through the Hotel Association of Hungary } \\
\text { from } 2010\end{array}$ \\
\hline
\end{tabular}

Note. Source: Foris (2010).

Analyzing the existence of the hotel classification system in the member states of the EU, we find the presence of a classification system in 27 of the countries, where only Finland has not adopted such a system.

The analysis of the hotel classification system adopted in the EU member states, in terms of its nature, reveals that 17 states have a formal system of classification, thus identifying the existence of a self-regulated system in 11 states and in Finland no system (voluntary informal or no) adopted.

Analyzing the hotel classification system adopted in the EU member states, in terms of division of powers in regulating the classification system, we find that in most countries, there are national regulations, only in Belgium, Spain, and Italy, we meet regional regulations, and in Finland, there is no regulation of this nature.

At the EU, we identify the countries that have acceded to the classification system Hotelstars: starting with 2010, Austria, Czech Republic, Germany, Sweden, Hungary (in 2010) as well as the Netherlands, Estonia (since 2011). The same system was applied in Switzerland since 2011.

Under the HOTREC (Hotels, Restaurants, \& Cafes in Europe) patronage, hotel associations of Austria, Czech Republic, Germany, Sweden, Hungary, and Switzerland have created the Hotelstars Union, partnership that follows a harmonious classification of hotels, based on similar criteria and procedures, applied in the mentioned countries.

Hotelstars classification system was launched on September 14, 2009, during a conference in Prague, being presented in Germany, Austria, Switzerland, Sweden, Czech Republic, the Netherlands, Hungary, and Estonia.

Not only do the classification systems vary from state to state, but there is also a significant diversity of types of tourist accommodation structures. 
We will present the types of structures with functions of tourist accommodation and their classification categories used in the member states of the EU (see Table 2).

Table 2

Types of Tourist Accommodation Structures and Classification Categories Used in Different States of the EU

\begin{tabular}{|c|c|c|c|}
\hline No. & Country & Type of tourist accommodation structures & Classification category/type of structures \\
\hline 1 & Austria & $\begin{array}{l}\text { Hotels, guest houses, pensions, Hotel Garni (bed } \\
\text { and breakfast }(B \& B) \text { ), and apartments }\end{array}$ & Hotels: $1-5$ stars \\
\hline 2 & Belgium & $\begin{array}{l}\text { Hotels, guest rooms, recreation fields, vacation } \\
\text { complex, and motels }\end{array}$ & Hotels: $1-5$ stars \\
\hline 3 & Bulgaria & $\begin{array}{l}\text { Hotels, motels, vacation complex, family hotels, } \\
\text { bungalows and camping sites, houses for rent, } \\
\text { separated rooms, vacation houses and houses }\end{array}$ & $\begin{array}{l}\text { Hotels: } 1-5 \text { stars } \\
\text { Motels: } 1-3 \text { stars } \\
\text { Vacation complex: } 3-5 \text { stars } \\
\text { Family hotels: } 1-3 \text { stars } \\
\text { Bungalows and camping sites: } 1-2 \text { stars } \\
\text { Houses for rent: } 1-3 \text { stars } \\
\text { Separated rooms, vacation houses and houses: } 1-3 \text { stars }\end{array}$ \\
\hline 4 & Cyprus & $\begin{array}{l}\text { Hotels, hotel apartments, touristic villages, } \\
\text { touristic villas, camping sites, traditional houses } \\
\text { (hotel and hotel apartments), and touristic } \\
\text { apartments }\end{array}$ & $\begin{array}{l}\text { Hotels: } 1-5 \text { stars } \\
\text { Hotel apartments, touristic villages, and touristic villas: } \\
\text { deluxe, A, B, and C categories } \\
\text { Camping sites: A and B categories } \\
\text { Traditional houses (classified as hotels and hotel } \\
\text { apartments) } \\
\text { Touristic apartments: without stars } \\
\text { Other categories: hotels without stars and guest houses }\end{array}$ \\
\hline 5 & $\begin{array}{l}\text { Czech } \\
\text { Republic }\end{array}$ & $\begin{array}{l}\text { Hotels, motels, pensions, camping sites, cabins, } \\
\text { guest bedrooms, and cabins on a ship }\end{array}$ & $\begin{array}{l}\text { Hotels: } \\
1 \text { star: Tourist } \\
2 \text { stars: Economy } \\
3 \text { stars: Standard } \\
4 \text { stars: First class } \\
5 \text { stars: Luxury } \\
\end{array}$ \\
\hline 6 & Denmark & Hotels, hostels & $1-5$ stars \\
\hline 7 & Estonia & $\begin{array}{l}\text { Hotels, motels, guest houses, hostels, touristic } \\
\text { villages and holiday camps, apartments for } \\
\text { visitors, and B\&B }\end{array}$ & $\begin{array}{l}\text { Hotels: } 1-5 \text { stars } \\
\text { Motels: } 1-3 \text { stars }\end{array}$ \\
\hline 8 & Finland & Hotels & Not applicable \\
\hline 9 & France & $\begin{array}{l}\text { Hotels, camping, hostels, tourism rooms, vacation } \\
\text { villages, touristic residential villages, hotel } \\
\text { prefectures, and residential entertainment parks } \\
\text { Hotels: (1) classified based on regulations until } \\
\text { 2009: touristic hotels, touristic residences; and (2) } \\
\text { classified based on regulations available from } \\
\text { July 2009: hotels }\end{array}$ & $\begin{array}{l}\text { Until } 2012 \text {, we identify two types of categories of hotel } \\
\text { classification: } \\
\text { (1) Hotels classified based on the regulations until July } \\
2009 \text { : } \\
\text { (a) touristic hotels: } 1-4 \text { stars as luxury } \\
\text { (b) Hotel prefectures: } 0 \text { star. } \\
\text { (c) Touristic residences: } 1-4 \text { stars } \\
\text { (2) Hotels classified based on the regulations from July } \\
\text { 2009: } 1-5 \text { stars }\end{array}$ \\
\hline 10 & Germany & $\begin{array}{l}\text { Hotels } \\
\text { G-classification: guest houses, taverns, inns, } \\
\text { pensions, etc. }\end{array}$ & $\begin{array}{l}\text { Hotels: } \\
1 \text { star: Tourist } \\
2 \text { stars: Standard } \\
3 \text { stars: Comfort } \\
4 \text { stars: First class } \\
5 \text { stars: Luxury } \\
\end{array}$ \\
\hline 11 & Greece & $\begin{array}{l}\text { Main structures: standard hotels, motels, } \\
\text { apartments with furniture, mixed type hotels, and } \\
\text { camping facilities } \\
\text { Secondary structures: rooms for rent, apartments } \\
\text { with furniture, and furnished houses and } \\
\text { mansions }\end{array}$ & $\begin{array}{l}\text { Hotels, apartments with furniture, and houses for rent: } \\
1-5 \text { stars } \\
\text { Camping: A, B, and C categories }\end{array}$ \\
\hline
\end{tabular}


(Table 2 continued)

\begin{tabular}{|c|c|c|c|}
\hline No. & Country & Type of tourist accommodation structures & Classification category/type of structures \\
\hline 12 & Ireland & $\begin{array}{l}\text { Hotels, guest houses, hostels for vacation, hostels } \\
\text { for youth, vacation camps, camping sites, } \\
\text { vacation houses, and vacation apartments }\end{array}$ & $\begin{array}{l}\text { Hotels: } 1-5 \text { stars } \\
\text { Guest houses: } 1-4 \text { stars } \\
\text { There are also hotels and guest houses unclassified, with } \\
\text { the symbols } U, N \text {, and R }\end{array}$ \\
\hline 13 & Italy & $\begin{array}{l}\text { There are four macro-categories: } \\
\text { (1) Hospitality establishments: Hotels, residencies } \\
\text { (2) Non-hospitality establishments: B\&B, hostels } \\
\text { for youth, private houses, and alpine refuges } \\
\text { (3) Outdoor establishments: touristic villages, } \\
\text { camping } \\
\text { (4) These categories can differ from one region to } \\
\text { another }\end{array}$ & $\begin{array}{l}\text { Hotels: two types of classification system at a regional } \\
\text { level ( } 21 \text { regions): } \\
\text { (1) The majority of the regions have adopted a system } \\
\text { based on six categories of classification: from } 1 \text { to } 5 \text { stars } \\
\text { deluxe, based on a minimum score for each category } \\
\text { (2) Ten regions are using a system based on five } \\
\text { categories of classification: from } 1 \text { to } 4 \text { stars deluxe } \\
\text { based on the mandatory classification criteria }\end{array}$ \\
\hline 14 & Latvia & $\begin{array}{l}\text { Hotels, guest houses, and motels } \\
\text { Other categories: Camping sites, hostels for youth }\end{array}$ & $\begin{array}{l}\text { Hotels: } 1-5 \text { stars } \\
\text { Guest houses, motels: I-IV categories } \\
\text { Camping sites, hostels for youth: I-III categories }\end{array}$ \\
\hline 15 & Lithuania & $\begin{array}{l}\text { Hotels, motels, and guest houses } \\
\text { Other structures: Camping, rest houses, } \\
\text { sanatorium, sanitarium health centers, touristic } \\
\text { centers, free time houses, and hostels for youth }\end{array}$ & $\begin{array}{l}\text { Hotels: } 1-5 \text { stars } \\
\text { Guest houses: } 1-4 \text { stars }\end{array}$ \\
\hline 16 & Luxembourg & \begin{tabular}{|l|l} 
Hotels, hotel apartments \\
\end{tabular} & $1-5$ stars \\
\hline 17 & Malta & $\begin{array}{l}\text { Hotels, aparthotels, vacation villages, guest } \\
\text { houses, hostels, and B\&B establishment }\end{array}$ & $\begin{array}{l}\text { Hotels: } 2-5 \text { stars } \\
\text { Aparthotels: } 2-5 \text { stars } \\
\text { Vacation villages: } 2-5 \text { stars } \\
\text { Guest houses: standard or comfort } \\
\text { Hostels: standard } \\
\text { B\&B establishment: } 2-3 \text { stars }\end{array}$ \\
\hline 18 & Great Britain & $\begin{array}{l}\text { Hotels: rural hotels, urban hotels, mini-hotels, and } \\
\text { metro-hotels } \\
\text { Guest accommodation structures: B\&B, guest } \\
\text { houses, farm houses, inns, restaurants with rooms, } \\
\text { and campus } \\
\text { Hostels: group hostels, housing activities, } \\
\text { sleeping cabins, and camping barns } \\
\text { Self-catering: apartments, authorized vacation } \\
\text { trailers } \\
\text { Ships: boats, cruise ships, and floating hotels } \\
\text { Vacation parks: touristic parks, camping, and } \\
\text { touristic villages }\end{array}$ & $\begin{array}{l}\text { There are four classification systems for: England, } \\
\text { Scotland, Wales, and Northern Ireland. Most of the } \\
\text { systems are based on the star system } \\
\text { Hotels: } \\
\text { (1) England: } 1-5 \text { stars } \\
\text { (2) Scotland and Wales: 0-5 classes: } \\
\text { (a) Class 0: AA } 1 \text { star } \\
\text { (b) Class 1: AA } 1 \text { star } \\
\text { (c) Class 2: AA } 2 \text { stars } \\
\text { (d) Class 3: AA } 3 \text { stars } \\
\text { (e) Class 4: AA } 4 \text { stars } \\
\text { (f) Class 5: AA } 5 \text { stars }\end{array}$ \\
\hline 19 & \begin{tabular}{|l|} 
The \\
Netherlands
\end{tabular} & Hotel, camping, and bungalow parks & Hotels: $1-5$ stars \\
\hline 20 & Poland & $\begin{array}{l}\text { Hotels, motels, pensions/guest houses, camping, } \\
\text { houses for tourists, hostels for youth, hostels, and } \\
\text { bivouac }\end{array}$ & $\begin{array}{l}\text { Hotels, motels, and pensions: } 1-5 \text { stars } \\
\text { Camping: } 1-4 \text { stars } \\
\text { Guest houses, houses for tourists, and hostels for youth: } \\
\text { I-III categories }\end{array}$ \\
\hline 21 & Portugal & $\begin{array}{l}\text { Structures of tourist accommodation: hotels, hotel } \\
\text { apartments, inns, touristic villages, touristic } \\
\text { apartments, resorts, vacation villas, structures of } \\
\text { tourist accommodation placed in the rural areas } \\
\text { (houses, structures for agro-tourism, and rural } \\
\text { hotels), camping, and trailers } \\
\text { Units of local housing }\end{array}$ & $\begin{array}{l}\text { Structures of tourist accommodation: } \\
\text { (1) Hotels, hotel apartments: } 1-5 \text { stars } \\
\text { (2) Inns: (a) located in a national monument building or } \\
\text { public interest: } 4 \text { stars; and (b) located in a building of a } \\
\text { local or public regional interest with historic or } \\
\text { architectural value: } 3 \text { stars } \\
\text { (3) Touristic villages: } 3-5 \text { stars } \\
\text { (4) Touristic apartments (vacation): } 3-5 \text { stars } \\
\text { (5) Resorts: have at least two accommodation structures, } \\
\text { one at least of } 4 \text { or } 5 \text { stars } \\
\text { (6) Accommodation structures placed in the rural areas: } \\
\text { cabins, structures for agro-tourism, rural hotels, } \\
\text { camping, and trailers: } 3-5 \text { stars } \\
\text { Local units of housing: no classification }\end{array}$ \\
\hline
\end{tabular}


(Table 2 continued)

\begin{tabular}{|c|c|c|c|}
\hline No. & Country & Type of tourist accommodation structures & Classification category/type of structures \\
\hline 22 & Romania & $\begin{array}{l}\text { Hotels, hotel apartments, motels, hostels, villas, } \\
\text { bungalows, touristic cabins, camping, vacation } \\
\text { villages, touristic stops, camping houses, } \\
\text { pensions, agro-touristic houses, apartments or } \\
\text { houses for rent, and accommodation structures } \\
\text { with housing on ships }\end{array}$ & $\begin{array}{l}\text { Hotels, villas, and housing structures on ships: } 1-5 \text { stars } \\
\text { Hotel apartments: } 2-5 \text { stars } \\
\text { Motels, hostels, bungalows, touristic cabins, and } \\
\text { apartments or rooms for rent: } 1-3 \text { stars } \\
\text { Camping, vacation villages, touristic stops, and camping } \\
\text { housing: } 1-4 \text { stars } \\
\text { Touristic pensions and agro-touristic houses: } 1-5 \\
\text { stars/flowers }\end{array}$ \\
\hline 23 & Slovakia & $\begin{array}{l}\text { Hotels (different categories), boatels, guest } \\
\text { houses, apartment houses, touristic hostels, } \\
\text { vacation villages, campground, camping sites, } \\
\text { and private housing }\end{array}$ & $\begin{array}{l}\text { Hotels (different categories) and boatels: } 1-5 \text { stars } \\
\text { Guest houses: standard and budget (economic), which } \\
\text { correspond to the hotel classification categories of } 1,2 \text {, } \\
\text { and } 3 \text { stars } \\
\text { Apartment houses: } 2-3 \text { stars } \\
\text { Touristic hostels and vacation villages: economic level, } \\
\text { medium, and superior } \\
\text { Campground and camping sites: four classes of } \\
\text { classification } \\
\text { Private housing: rural tourism and agro-tourism }\end{array}$ \\
\hline 24 & Slovenia & $\begin{array}{l} \\
\text { Hotels, motels, pensions, inns, youth camps, } \\
\text { apartments, vacation houses, private rooms, } \\
\text { accommodation at a farm house, and marinas }\end{array}$ & $\begin{array}{l}\text { Hotels: } 1-5 \text { stars } \\
\text { Youth camps: } 1-5 \text { stars } \\
\text { Motels, pensions, inns, vacation houses, and private } \\
\text { rooms: } 1-4 \text { stars } \\
\text { Accommodation at a farm house: } 1-4 \text { apples }\end{array}$ \\
\hline 25 & Spain & $\begin{array}{l}\text { Hotels, Hotel Garni, hotel apartments } \\
\text { condominium, motels, boatels, rotels, hostels, } \\
\text { camping, private rooms, refuges, guest houses, } \\
\text { rural houses, cruise ships, and resorts }\end{array}$ & $\begin{array}{l}\text { Hotels: 1-5 stars } \\
\text { Secondary group: } \\
\text { (1) Private rooms and rural houses: 1-3 stars } \\
\text { (2) Hostels: 1-3 stars } \\
\text { (3) Motels: correspond to 2-star hotels } \\
\text { (4) Guest houses: no category } \\
\text { In some regions, in the classification system, a "superior } \\
\text { class" can be included for the superior level hotels: } \\
\text { golden stars, and for private rooms, rural houses, and } \\
\text { hostels: silver stars }\end{array}$ \\
\hline 26 & Sweden & Hotels, Hotel Garni & $1-5$ stars \\
\hline 27 & Hungary & $\begin{array}{l}\text { Hotels: } \\
\text { (1) classified based on the mandatory rules: } \\
\text { hotels, hydropathic hotels, wellness hotels, Hotel } \\
\text { Garni, and hotel apartments } \\
\text { (2) classified based on Hotelstars, starting with } \\
\text { 2010: hotels } \\
\text { Other structures: pensions, camping, vacation } \\
\text { houses, hostels, and touristic pensions }\end{array}$ & $\begin{array}{l}\text { Hotels classified based on the mandatory rules: } \\
\text { (1) Hotels: } 1-5 \text { stars } \\
\text { (2) Hydropathic hotels: } 2-5 \text { stars } \\
\text { (3) Wellness hotels: } 3-5 \text { stars } \\
\text { (4) Hotel Garni: } 1-4 \text { stars } \\
\text { (5) Hotel apartments: } 3-5 \text { stars } \\
\text { Hotels classified based on Hotelstars system which is } \\
\text { implemented in } 2010 \text { : } \\
\text { (1) } 1 \text { star: Tourist } \\
\text { (2) } 2 \text { stars: Economy } \\
\text { (3) } 3 \text { stars: Standard } \\
\text { (4) } 4 \text { stars: First class } \\
\text { (5) } 5 \text { stars: Luxury }\end{array}$ \\
\hline 28 & Croatia & $\begin{array}{l}\text { Hotels, hotel apartments, camping, and other } \\
\text { types of accommodation structures: hostels, } \\
\text { rooms, and apartments }\end{array}$ & $1-5$ stars \\
\hline
\end{tabular}

Note. Source: Adapted from The European Consumer Centres' Network (2009).

Analysis of the establishments of tourist accommodation and their classification categories used in the EU member states leads to the following conclusions.

There is a diversity of structures with functions of tourist accommodation which are different and they have specific nomination categories differing from country to country. 
Establishments of tourist accommodation can be divided into three main classes:

(1) Hotel structures;

(2) Non-hotel structures;

(3) Outdoor structures.

We believe that each main class corresponds to the following main types of structures with functions of tourist accommodation:

(1) Hotel structures: hotels;

(2) Non-hotel structures:

(a) Pension B\&B;

(b) Hostels;

(c) Cabins;

(d) Apartments and touristic rooms.

(3) Outdoor structures: camping.

Hotels, as the main structure of touristic accommodation, can have the following sub-types:

(1) Hotels;

(2) Hotel apartments;

(3) Motels;

(4) Specialized hotels: vacation, business, conferences, health and wellness;

(5) Floating hotels (boatels);

(6) Unique hotels (boutique hotels);

(7) Resorts.

Regarding the classification system with functions of tourist accommodation in most EU countries, this is based on the star system, which can range from 1 to 5 stars (except in Italy, where, in most regions, for the hotel classification system is used a system based on six categories, from 1 star to 5 star deluxe, and the other 10 regions, a system based on five categories, from 1 star to 4 star deluxe), but other systems are encountered, such as system categories (in Cyprus, hotel apartments, tourist villages, and villas are classified by categories: Deluxe, A, B, and C; in Latvia, motels and guest houses are graded from I to IV), on classes (for classification of hotels in Scotland and Wales: Class 0-5), on flowers (for classification of guesthouses in Romania, from 1 to 5 flowers), on apples (for classifying farm house accommodation in Slovenia, from 1 to 4 apples) etc., but we identify the use of a higher class (in countries using the Hotelstars system, the supplement "superior", or "golden" stars for hotels in Spain, and "silver" stars for rural houses, hostels, and private rooms).

In the EU, not only do the hotel classification systems vary from country to country, but there is also a significant diversity in the level of comfort related to the level and criteria of classification, which differ from one state to another, an aspect that complicates even more the accuracy of the information provided by the ranking system in the eyes of tourists.

This is the reason why one of the priorities in the field tourism is to improve the quality of tourism by harmonizing the classification standards in the field.

\section{Quality Mark in Hospitality}

In its working schedule, the United Nations World Tourism Organization (UNWTO, 2003) operates with the quality concept in tourism, defined as: 
The result of a process which implies the satisfaction of all the legitimate product and service needs, requirements, and expectations of the consumer, at an acceptable price, in conformity with mutually accepted contractual conditions and the underlying quality determinants such as safety and security, hygiene, accessibility, transparency, authenticity, and harmony of the tourism activity concerned with its human and natural environment ${ }^{1}$.

The quality mark in the hotel industry is an instrument that evaluates the quality of the work done by tourism providers, in relation to a predetermined set of standards through which written and formalized procedures are made, which helps companies evaluate the service quality, with regard to the expectations and the needs of tourists. The quality mark is awarded through a mark certificate, issued by an authorized body in the respective field, receiving the mark that represents an attestation and a guarantee for the high quality of tourism services and products offered.

The quality mark is a model of good practices for implementing and certifying the quality of hotel services, as a voluntary option of the economic operators in the field.

The purpose of the quality mark is to improve the quality of services provided by the hotel accommodations for raising the satisfaction level of clients and for guaranteeing that they will benefit in any evaluated and certified hotel accommodation, from a high level of quality services, regardless of the accommodation category.

The quality mark's objectives in the hospitality field are as follows:

(1) Developing and applying the model of best practices for implementing and certifying the quality of hotel services, for generating the satisfaction of customers, and for developing the competitiveness of hotel accommodations, by harmonizing the hotel services with the needs, expectations, and requirements of users;

(2) Application, inside the hotel industry, of an internal and external service quality system, a system to become an effective management tool, designed to develop the quality of provided services.

The quality mark's principles refer to the following aspects:

(1) The mark will favor the use of standards ("what do I do?") with operating procedures ("how do I do?");

(2) The marking will be done uniformly;

(3) Implementation of the mark in as many categories of hotel units as possible;

(4) Voluntary procedures, so that the management of every hotel will decide if they want to implement and apply for the quality mark.

Brand quality for hotel accommodations is created by starting from the steps contained in the tourism value chain (reservation, arrival, room, stay, pay, and the contact after the visit), and the elements from every step will represent the quality criteria. These criteria will be used for estimating the quality level of the services, and in the end, for applying the mark or not.

The basis of such a model of good practices, for implementing and certifying the hotel service quality, is the criteria for: management, staff performances, accessibility/location, building facade/exterior spaces/parking lot, common areas, hotel lobby/reception, rooms/bathrooms, breakfast/restaurant/bar/room service, customer services, supply, and communication.

The quality mark of the hotel industry has the following features:

${ }^{1}$ Retrieved from http://www.sdt.unwto.org/en/content/quality-tourism. 
(1) In order to cover the whole diversity of the hotel unit, the brand must be configured on a whole set of criteria (and not just on a few criteria);

(2) The criteria of the brand must be relevant, well-defined, and depend on the present and future expectations of the customers;

(3) The mark must be transparent and must point out in a clear way the level of the realized service;

(4) The mark must differentiate, in a clear and convincing way, the high-end hotels from the low-tier ones;

(5) The mark must be easy to manage and adaptable to future changes;

(6) The mark must be just and objective.

"The symbol stating that the hotel is entrusted with providing quality hotel services" can be defined as the quality label.

In the EU, the European Committee is currently working an umbrella European tourism label for quality schemes (European Commission, 2014), to:

(1) Increase consumer security and confidence in tourism products;

(2) Encourage tourism professionals who make genuine efforts to improve services.

At present, there are many existing quality schemes for hospitality sectors across Europe, which vary greatly in terms of scope, assessment criteria, and procedures (see Table 3).

Table 3

Quality Schemes for Hospitality Sectors in the EU Member States

\begin{tabular}{|l|l|l|l|}
\hline No. & State & Quality mark/scheme & Organization \\
\hline 1 & Bulgaria & Authentic Bulgaria & Private \\
\hline 2 & Czech Republic & NTQS: National Tourism Quality System & Public \\
\hline 3 & Denmark & Active Denmark & Public-private cooperation \\
\hline 4 & Estonia & $\begin{array}{l}\text { Estonian Tourism Quality Programme (People } \\
\text { Committed to Quality) }\end{array}$ & Public \\
\hline 5 & Finland & $\begin{array}{l}\text { Destination Quality Net (DQN) Program } \\
\text { Quality 1Q00 }\end{array}$ & Public-private cooperation \\
\hline 6 & France & $\begin{array}{l}\text { Qualité Tourisme } \\
\text { Camping Qualité }\end{array}$ & Public-private cooperation \\
\hline 7 & Germany & Service Qualität Deutschland & Private \\
\hline 8 & Greece & Q label & Private \\
\hline 9 & Ireland & Quality Assurance & Public \\
\hline 10 & Italy & Ospitalità Italiana & Private \\
\hline 12 & Great Britain & Visit Wales & Public \\
\hline 13 & Spain & SICTED ${ }^{3}$ : Calidad Turistica & Private \\
\hline 14 & Sweden & Sustainable Travel Industry Sweden cooperation \\
\hline 15 & Hungary & Hungarian Tourism Quality Award & Private \\
\hline
\end{tabular}

We can also identify the quality mark European Hospitality Quality, developed by HOTREC (2013) and applied in the Czech Republic, Hungary, Germany, and Sweden, as well as Hostelling International Quality, developed by Hostelling International Association, acting globally for hostels.

\footnotetext{
${ }^{2}$ Government Decision No. 668/05.06.2003 on the national program to increase the quality of hotel services and the launch of "Q" mark (Ministry of Tourism, 2003).

${ }_{3}^{3}$ Program aimed to improve the quality of tourist destinations by working with tourism companies/services in the up to 29 different categories that make up the experience and satisfaction a tourist has visiting each destination (Grand Canaria, 2013). Retrieved from http://www.grancanaria.com/patronato_turismo/sicted_en.0.html\#sthash.ap2WoBsk.dpuf.
} 
Analyzing the existence of quality types of hotel brands in the member states of the EU, we find the presence of such a system in 15 states.

The analysis of quality hotel brands existing in the member states of the EU, from its nature point of view, emphasizes the fact that in six states, the system is given by the private organizations, in five states, the mark is given through a quality official system, and in four states, the public-private cooperation system can be found.

Each quality scheme is characterized by different criteria used to measure the quality and therefore to grant the label. Among all possible criteria, those directly concerning the features of the services provided are the most important. All quality schemes usually measure the quality through customer satisfaction survey, and the presence of a system to constantly control the quality for tourists is necessary. Many labels check the level, number and efficiency of the facilities, and other amenities available for tourists. Also important is the implementation of human resource policies for improving the quality of them and checking the truthfulness of advertising messages and other forms of communication.

\section{Comparative Analysis of Classification System of Hotel Classification and Quality Label in Hospitality}

Next, we perform a comparative analysis of hotel classification system and quality label in hospitality, using a set of 10 analysis criteria: definition, foundation, scope, regulation, purpose, objectives, typology of system, characteristics, features criteria, and benefits (see Table 4).

Table 4

Comparative Analysis of Hotel Classification System and Quality Label in Hospitality

\begin{tabular}{|c|c|c|c|}
\hline No. & Analysis criteria & Classification system of tourist accommodation & Quality mark \\
\hline 1 & Definition & $\begin{array}{l}\text { A coded form of synthesis of comfort level and } \\
\text { range of services }\end{array}$ & $\begin{array}{l}\text { The symbol stating that the hotel is entrusted with } \\
\text { providing quality hotel services }\end{array}$ \\
\hline 2 & Foundation & $\begin{array}{l}\text { Foundation on notoriety, moral climate, and a set of } \\
\text { standards of services and facilities }\end{array}$ & $\begin{array}{l}\text { Model of best practices for implementation and } \\
\text { certification of hotel services quality }\end{array}$ \\
\hline 3 & Scope & $\begin{array}{l}\text { It differs from country to country } \\
\text { There are few countries that have not adopted a } \\
\text { classification system }\end{array}$ & $\begin{array}{l}\text { It is applied in some countries to reach a quality } \\
\text { standard to match the requirements of tourists }\end{array}$ \\
\hline 4 & Regulation & Compulsory/voluntary & Voluntary \\
\hline 5 & Purpose & $\begin{array}{l}\text { Synthesis of the comfort level and the range of } \\
\text { services related to the respective category }\end{array}$ & $\begin{array}{l}\text { Improving service quality of hotel units in order to } \\
\text { increase the level of customer satisfaction and to } \\
\text { ensure them that they will benefit by a high level of } \\
\text { service quality, regardless of the category of } \\
\text { the unit, in any of the evaluated and certified hotel } \\
\text { units }\end{array}$ \\
\hline 6 & Objectives & $\begin{array}{l}\text { Informing customers } \\
\text { The ability to distinguish tourist accommodations by } \\
\text { implementing differentiated policies } \\
\text { A possible tariff regulation } \\
\text { Facilitating communication, concluding contracts, } \\
\text { and monitoring their compliance, in the relationship } \\
\text { between hotels and travel agencies }\end{array}$ & $\begin{array}{l}\text { Development and implementation of a model of } \\
\text { best practices for the implementation and } \\
\text { certification of hotel services quality, to generate } \\
\text { customer satisfaction and development of hotel } \\
\text { units competitiveness, by harmonizing hotel } \\
\text { services with needs, expectations, and } \\
\text { requirements of users } \\
\text { Application, within the hotel industry, of a system } \\
\text { of internal and external evaluation of the } \\
\text { quality of services provided, a system that will } \\
\text { become an effective management tool, designed } \\
\text { to develop the level of quality of services } \\
\text { provided }\end{array}$ \\
\hline
\end{tabular}


(Table 4 continued)

\begin{tabular}{|c|c|c|c|}
\hline No. & Analysis criteria & Classification system of tourist accommodation & Quality mark \\
\hline 7 & $\begin{array}{l}\text { Typology of } \\
\text { system }\end{array}$ & $\begin{array}{l}\text { In most states, it is based on the star system, which } \\
\text { can range from } 1 \text { to } 5 \text { stars (except in Italy), but } \\
\text { there are other systems, such as the category system } \\
\text { (in Cyprus), class system (Scotland and Wales), on } \\
\text { flowers (Romania), on apples (Slovenia), and others, } \\
\text { but we identify the use of a higher class (Hotelstars } \\
\text { system: superior; in Spain: gold stars; or silver stars) }\end{array}$ & $\begin{array}{l}\text { It is based on assigning the mark, the symbol. } \\
\text { Also, there are quality brands that comprise } \\
\text { several categories (Switzerland: } 3 \text { categories) }\end{array}$ \\
\hline 8 & Characteristics & $\begin{array}{l}\text { Category classification is determined by the } \\
\text { fulfillment of requirements and classification } \\
\text { criteria, specific to each type of structure and } \\
\text { classification category }\end{array}$ & $\begin{array}{l}\text { It will favor the use of standards ("what do I } \\
\text { do?") with operating procedures ("how do I } \\
\text { do?"). Quality mark for hotel units will be created } \\
\text { from the stages contained in the tourism value } \\
\text { chain (reservation dates, room, stay, payment, and } \\
\text { contact after visit), and the elements of each stage } \\
\text { will be the quality criteria. These criteria will be } \\
\text { used to appreciate the level of services quality, } \\
\text { and finally to apply or not the mark }\end{array}$ \\
\hline 9 & Features criteria & $\begin{array}{l}\text { Classification criteria of tourist accommodation } \\
\text { shall take into account: } \\
\text { (1) The comfort level } \\
\text { (2) Territorial location } \\
\text { (3) Motivation of functionality } \\
\text { (4) Duration of stay } \\
\text { (5) The operating mode of the system } \\
\text { (6) Form of ownership } \\
\text { (7) Form of exploitation } \\
\text { (8) Capacity } \\
\text { (9) Market target } \\
\text { (10) The standard of services and facilities offered }\end{array}$ & $\begin{array}{l}\text { Basis of such a model of best practice for the } \\
\text { implementation and quality certification of hotel } \\
\text { services shall constitute criteria concerning: } \\
\text { (1) Management } \\
\text { (2) Performances staff } \\
\text { (3) Accessibility/“SL" position } \\
\text { (4) Building facade/exterior spaces/parking lot } \\
\text { (5) Common areas } \\
\text { (6) Hotel lobby/reception } \\
\text { (7) Rooms/bathrooms } \\
\text { (8) Breakfast/restaurant/bar/room service } \\
\text { (9) Customer services } \\
\text { (10) Supply } \\
\text { (11) Communication }\end{array}$ \\
\hline 10 & Benefits & $\begin{array}{l}\text { Providing direct channels of promotion, control, and } \\
\text { safety standards that are consistent with tourist } \\
\text { expectations } \\
\text { Contribution to the formation of the image of } \\
\text { confidence }\end{array}$ & $\begin{array}{l}\text { Improving the image of the hotel } \\
\text { Efficiency of activities and services } \\
\text { Customer loyalty } \\
\text { Reducing costs } \\
\text { Increasing labor productivity }\end{array}$ \\
\hline
\end{tabular}

\section{Conclusions}

Hotel classification is a coded form of synthesis of comfort level and range of services, and the quality label is a model of good practices for implementation and certification of the hotel services quality. The classification system may be compulsory or voluntary (varies from country to country), while the quality mark is always voluntary. Classification of hotels is based on the star system (1-5 stars), and the quality brand is based on awarding the quality mark symbol. Objectives taken into account by adopting a system of classification refer to: tourists information, the possibility of contrast of hotels by implementing a differentiated policy, facilitate communication, conclusion of contracts, and monitoring compliance with the relationship between hotels and tourists, while the objectives envisaged through the adoption of a quality brand relate to generate tourist satisfaction, building competitiveness of the tourist accommodation.

Quality certification services by quality mark do not intend to replace administrative classification or standards in force, but intend to supplement them, and in the long term, harmonize various existing categories and sub-categories, rather heterogeneous tourist market at present. For this purpose, the services offered by the tourist accommodation are evaluated in terms of the customer. Thus, the tourist accommodation must not only declare a list of facilities and services, but also deliver them to certain quality standards. 


\section{References}

Centre for European Policy Studies. (2012). Estimated impacts of possible options and legal instruments of the umbrella European tourism label for quality $\quad$ schemes. $\mathrm{http} / /$ ec.europa.eu/enterprise/newsroom/cf/itemdetail.cfm?item_id=6236\&lang=en

European Commission. (2014). European tourism quality principles. Retrieved from $\mathrm{http}$ ://ec.europa.eu/enterprise/sectors/tourism/quality-label/index_en.htm

Foris, D. (2010). Authority and public administration in tourism (Ph.D. thesis, the National School of Political and Administrative Studies, Bucharest).

Foris, D. (2011). Regulation of tourist activities (p. 17). Braşov: Publishing Lux Libris.

Grand Canaria. (2013). What is SICTED? Retrieved from http://www.grancanaria.com/patronato_turismo/sicted_en.0.html

Hotels, Restaurants, \& Cafés in Europe [HOTREC]. (2013). European hospitality quality. Retrieved from http://www.hotrec.eu/policy-issues/quality.aspx

Ministry of Tourism. (2003). Government Decision No. 668/05.06.2003 on the national program to increase the quality of hotel services and the launch of Romanian “ $Q$ ” mark. Government Printing Office M. O. No. 424/17.06.2003.

The European Consumer Centres' Network. (2009). Classification of hotel establishments within the EU. Retrieved from http://ec.europa.eu/consumers/ecc/docs/hotel_establishment_classification_EU en.pdf

United Nations World Tourism Organization [UNWTO]. (2003). Quality in tourism. Quality Support Committee at its sixth meeting, Varadero, Cuba. Retrieved from http://sdt.unwto.org/en/content/quality-tourism 